\title{
The rise and fall of a policy: policy succession and the attempted termination of ecological corridors policy in the Netherlands
}

\author{
Esther Turnhout
}

Published online: 6 February 2009

(C) The Author(s) 2009. This article is published with open access at Springerlink.com

\begin{abstract}
In policy analysis, studies on policy termination are rare. This article offers such a study. It presents the story of how, despite attempts by the government to terminate it, Dutch nature policy on ecological corridors continued to be implemented by regional governments and in the field. A case analysis is presented that integrates theories and insights not only from the termination literature but also from the literature on implementation. The different factors identified in the literature that enable or constrain implementation and termination have served as a basis for developing possible explanations of the case study. They cannot, however, serve as generic theories with predictive power. Policy termination as well as policy implementation are highly contextual processes and the question which factors will enable or constrain policy termination and implementation can only be answered on a case by case basis.
\end{abstract}

Keywords Policy termination · Policy implementation · Policy succession · Interpretative policy analysis $\cdot$ Nature conservation policy $\cdot$ Ecological corridors

\section{Introduction}

In 2005, the Dutch parliament adopted a motion to call "on government to [...] fulfill all legally binding and administrative commitments regarding the ecological corridors and [...] come to a final decision about the financial arrangements regarding the ecological corridors [...]" (Tweede Kamer 2005). In this motion, the Dutch parliament expressed its opinion that the government should only finance those ecological corridors for which legal and administrative commitments had been made. It marked a key moment in the rather long and cumbersome process to terminate the ecological corridors policy in the Netherlands.

In policy analysis, policy termination is not studied frequently. According to De Leon (2002), the current lack of empirical studies on policy termination has resulted in a

E. Turnhout $(\bowtie)$

Forest and Nature Conservation Policy Group, Wageningen University, Wageningen, The Netherlands e-mail: esther.turnhout@wur.nl 
fragmented picture that does not allow for the formulation of an adequate theory on policy termination. This article contributes to the academic debate about policy termination by presenting a case study of how the Ministry of LNV (Landbouw, Natuurbeheer en Voedselkwaliteit, the Dutch ministry of Agriculture, Nature and Food Quality) tried to terminate the ecological corridors policy and replace it with the alternative robust corridors policy. The ecological corridors policy, however, resisted termination and continued to be implemented in lower levels of government and in the field. Four years after the first decision to terminate the ecological corridors policy, the Dutch government found itself in the situation of having to finance a considerable part of the ecological corridors that were planned by the regional governments.

This case study can only be fully understood if it is analyzed in terms of policy termination as well as in terms of the rapid implementation of the ecological corridors policy. Therefore, the article includes relevant insights from the policy science literature about policy implementation as well as termination. The next section further elaborates on the theoretical issues relevant for this article. Sections 3 and 4 present the case study. The article concludes with a discussion of policy termination and the theoretical and methodological implications of the case study.

\section{Studying policy termination}

Policy termination is considered by Lasswell (1971) to be the final stage of his seven-stage decision process and is defined as: "the decision [...] made by legislators and other authorities authorized by official prescription to put an end to an established arrangement." Policy termination is a rare subject in policy analysis. This conclusion can be found in the introductions of each of the three special issues of journals dedicated to policy termination: Policy sciences in 1976 (Bardach 1976) and International journal of public administration in 1997 (Daniels 1997) and 2001 (Daniels 2001). Bardach (1976) attributes this to the fact that "it is hard to study such an infrequent phenomenon as policy termination." Geva-May (2001) adds to this by claiming that policies are rarely ended and that governments - as do institutions in general-exhibit a tendency for maintaining stability (Geva-May 2001). Even more so, taking a decision to terminate a certain policy does not guarantee its actual termination in policy practice. It is difficult to actually change things "on the ground" and, as Frantz (2002) demonstrates, policies may survive for years after being officially terminated. Daniels (2001) argues against this assumed infrequency of policy termination. In his view, there are plenty of (attempted) terminated policies waiting to be studied, but there seems to be a lack of interest of the academic community. According to Daniels (2001), researchers prefer to focus on new innovative policies and have a preference for studying policy formulation or implementation. Perhaps "researchers prefer to focus on beginnings, not endings" (Frantz 1992).

Whatever the reasons, policy termination remains, in Daniels' (2001) words, an underattended issue. According to De Leon (2002), the current lack of empirical studies on the issue has resulted in a fragmented picture that does not allow for the formulation of an adequate theory on policy termination. Despite the absence of such a unifying theory, authors have tried to identify regularities in policy termination processes of policy termination. De Leon and Hernández-Quezada (2001) have identified several obstacles which can be grouped in two main categories: (1) obstacles related to the nature of organizations, namely their tendency to persist; (2) obstacles related to the emotional, financial, legal, or political costs of termination (Geva-May 2001). 
Policy termination is considered to be a thoroughly political process in which "fundamental questions of values and ideologies, rather than economies and efficiencies, provide the grounds for termination" (De Leon 2002). This means that arguments or scientific evaluations that point to a (the lack of) efficacy or efficiency, of a certain policy are not sufficient to actually achieve its termination. Such a conclusion resonates with analyses of the use and non-use of scientific knowledge. Several studies from the field of Science and Technology Studies have shown how processes of use and non-use of scientific knowledge in policy are influenced by social, cultural, and political values and interests (Collingridge and Reeve 1986; Turnhout 2003; Turnhout et al. 2007, 2008). In practice, instrumental use of knowledge is rare and knowledge is much more often used as advocacy or enlightenment (Weiss 1991). Frantz (2002) acknowledges the political character of policy termination and argues that policy terminators should make better use of political skills and resources. Examples of potentially successful strategies are: to match the termination strategy with the expected intensity of the resistance against termination; to take advantage of policy windows of opportunity; to build coalitions; to create support; and to identify the expected costs of termination and deal with them explicitly (Geva-May 2001).

The current rarity of studies on policy termination may also be explained by the difficulties involved in defining and operationalizing the concept of policy termination. One indication of this is given by Daniels (2001), who describes several interesting case studies that are potential cases of policy termination but are not recognized as such because they simply have not been analyzed or conceptualized in those terms. Policy termination is a confusing concept because it not only refers to the last stage in the so-called policy cycle, as suggested by Lasswell (1971), but can also be seen as an entire policy process in itself: the idea to terminate a certain policy " $\mathrm{A}$ " needs to be put on the political agenda; a new policy " $\mathrm{B}$ " which proposes the termination of policy " $\mathrm{A}$ " needs to be formulated and adopted and the implementation of policy " $\mathrm{B}$ " results in the termination of policy " $\mathrm{A}$ " (Bardach 1976). Furthermore, policies are rarely terminated without any replacement and can thus be conceptualized as policy change or succession (Hogwood and Peters 1982). Hogwood and Peters (1982) have criticized the literature on policy termination because it fails to acknowledge this and treats termination too much as an isolated phenomenon: "to emphasize termination in such situations is rather like talking about the death of the caterpillar without mentioning the birth of the butterfly." This is a very important point and the author agrees that policy termination should not be studied in isolation. However, the caterpillar-butterfly analogy only partly applies. While the caterpillar does not die but transforms into a butterfly, policy succession does involve the endings of old policies and the beginnings of the new policies. Rather than a separate process, isolated from its wider context, policy termination is part and parcel of any process of policy succession or change. The case study that is presented in this article focuses on the process of terminating the ecological corridors policy as part of the process of policy succession in which the ecological corridors policy was replaced with the alternative robust corridors policy.

As part of the wider context of policy termination, this article takes into account the process of policy implementation. The relevance of this is clear: policy termination requires not only an official decision to terminate a certain policy, but also the implementation of that decision and achieving termination in practice involves putting an end to the implementation of the officially terminated policy. This opens up interesting avenues for theoretical discussion in the sense that insights from the literature on policy implementation can now be included. 
The traditional literature on policy implementation has shown that policy implementation is rarely unproblematic. Sabatier and Mazmanian (1981), for example, argue that successful implementation depends on various factors such as sufficient incentives and budgets, effective communication, and clarity of policy goals. More recently, several authors have emphasized the role of interpretation and ambiguity in policy implementation. Instead of the unproblematic application of previously set policy goals by lower levels of government, implementation involves local actors, or street-level bureaucrats (Hill 2003), who reinterpret and renegotiate policies to fit local needs and circumstances (Yanow 1996; Dekker et al. 2007).

Both policy termination and policy implementation are highly contextual processes, in which not only central government but also other governmental and non-governmental actors play an active role in the renegotiation and reinterpretation of government policies and decisions. Depending on the context, some policies may be implemented without major adaptations or problems, and others may be renegotiated and reshaped and again others may be actively resisted. In this way, the factors that affect implementation or termination as discussed in the literature do make sense, not as variables of generic theories with predictive power, but as starting points of possible explanations that can be developed only after detailed case study research. In line with this argument, this article presents a case study that is analyzed by focusing not only on the decision to terminate ecological corridors policy in the Netherlands, but also on the implementation of this decision and on the implementation of the ecological corridors policy itself.

The article is based on a study of relevant policy documents and on 11 interviews with civil servants and scientific researchers involved in policy and research on ecological corridors (see the annex for an overview). The interviews were carried out by Hilde Visser as part of her Master Thesis research (published in Visser 2006) and the author wishes to express her gratitude for the excellent job she did.

\section{The rise and fall of Dutch ecological corridors policy}

This section describes the first part of the case study: the background and development of the Dutch ecological corridors policy, the emergence of a critical view on ecological corridors, and the beginnings of the alternative robust corridors policy.

Ecological corridors as the answer to the defragmentation of nature

Nature policy in the Netherlands made a head start with the adoption of the 1990 Nature Policy Plan (LNV 1990). This plan aims at realizing a national ecological network (NEN) in the Netherlands. The Dutch NEN consists of existing nature areas, nature development areas, and ecological corridors. These ecological corridors are envisioned to connect fragmented nature areas throughout the country, enable the migration of species, and improve the overall ecological quality of Dutch nature. The ecological basis of the assumed ecological importance of connectivity can be found in the theories of island biogeography (MacArthur and Wilson 1967) and metapopulations (Hanski and Gilpin 1997). Island biogeography states that the total species diversity of an island is based on a dynamic balance between extinction and colonization, which is influenced by the distance to the source area and by the size of the island. Thus, larger islands closer to source areas are predicted to contain more species. It was argued that nature in the Netherlands is so fragmented that nature sites can be considered as islands in a sea of cultivated landscape. In such a fragmented landscape, species are 
vulnerable to extinction because migration is too difficult. Metapopulation theory has essentially the same message but focuses on terrestrial areas and emphasizes the importance of migration between different populations of a single species.

These ecological theories have been very influential in Dutch nature policy. An ecologist from Alterra (Wageningen University and Research Center) ${ }^{1}$ involved in ecological corridors research said the following about the relation between ecological science and Dutch nature policy in this case:

It started somewhere in the 1980s [...it was realized] that habitat fragmentation is a problem. [...] Research in the 1980s was focused on that. As a result, policy became aware that biodiversity loss was partly the result of a lack of connectivity (R1).

Connectivity was the obvious answer to the issue of habitat fragmentation. It was not clear, however, how to this connectivity could be realized in the Netherlands, where the ecological corridors could be planned, or what criteria could be used to plan them. Still, the Nature Policy Plan contains a map of the Netherlands with the NEN drawn onto it, including some black arrows: the ecological corridors (see Fig. 1). With regard to the content of the ecological corridors policy, the Nature Policy Plan gives little more than the following description: "Ecological corridors are areas or structures that enable distribution, migration and exchange of species between different core areas" (LNV 1990). The policy was not really clear or well elaborated and according to an Alterra researcher:

There were no concrete targets (R2).

How did this map come into existence? The director general of LNV recalled:

We designed a map, a sketch with [...] the ecological corridors. Those were the 225 ecological corridors, the little ones. [...] As arrows on the map (R3).

According to a former LNV civil servant, now working for the Dutch Environmental Assessment Agency, such a map was necessary because it would make their ideas for nature concrete and because it could convince the minister of the importance of these ideas:

Somebody had to draw a map. A vague concept was made concrete with a map [...] and that map was shown to the minister and he said "yes, we are going to do this" (R4).

According to an Alterra ecologist, this map was really just a sketch that was not based on any scientific background because researchers were not involved at this stage:

It was really all put together in an afternoon. Research was not involved; we were just not ready yet. It is really nothing more, or less, than the existing nature sites with some high potential nature development sites $[\ldots]$ and some $[\ldots]$ arrows on the map: the ecological corridors (R1).

Despite this lack of scientific foundation, the concept of ecological corridors was quickly taken up by the regional governments:

[Those arrows] were put on the map by me and I tried to have as little of them as possible, but then, after the consultation [with the regional governments], the number increased (R4);

1 Alterra is part of Wageningen University and Research Center and it is the major research institute in the field of Environment and ecology for the Ministry of LNV (www.alterra.wur.nl). 


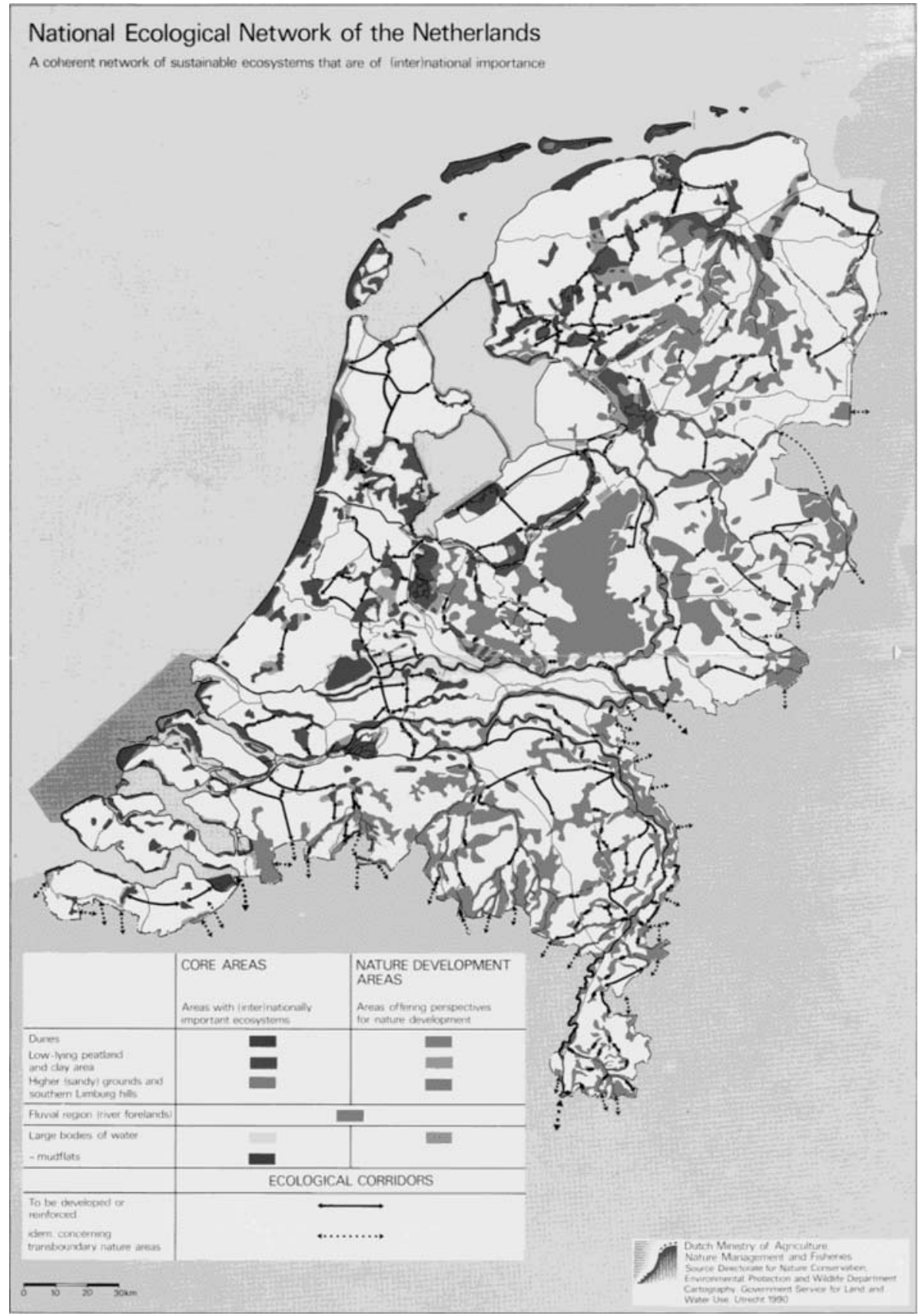

Fig. 1 Map of the Dutch National Ecological Network (LNV 1990)

[After the publication of the map in the Nature Policy Plan] the regional governments started working on the NEN and they doubled the amount of ecological corridors (R3) 
The NEN and the ecological corridors constituted a new, fresh, ambitious, and appealing nature conservation strategy, something which was desperately needed in Dutch nature policy. The director general of LNV said:

We always had negative and pessimistic nature policy about things that did not go well, bad environmental conditions, desiccation, loss of nature. Now the answer is: ambitious nature policy, combating pollution, desiccation, if nature is too small: enlarge it, defragmentation (R3).

Besides, the concept of ecological corridors was very attractive:

It was a Public Relation story. The idea that nature is fragmented and that animals, just like people, need connections, was just wonderfully simple (R4);

Although not a lot of research was done on the issue, people could visualize and imagine how it works. [...] Animals should be able to move [...] that is what caught the attention (R1).

What these quotes make clear is that, apparently without input of scientific knowledge, some LNV civil servants drew the ecological corridors onto a map of the NEN. With this map, the ecological corridors policy came into existence without being clearly defined. Despite this lack of foundation or clarity, the concept proved appealing and it was rapidly implemented. The next section will show that the success of the ecological corridors policy created some financial difficulties. In addition, scientists became involved and formulated not only scientific criticisms of the ecological corridors but also a scientifically founded alternative: the robust corridors.

\section{A critical view on ecological corridors}

In the 1990s, it became clear that the ecological corridors planned by the regional governments would not suffice. For example, the Nature Outlook of 1997 stated the following: "Although there is considerable progress in the planning of the ecological corridors by the regional governments, their ecological efficacy can be questioned" (RIVM, IKC-N, SCDLO, IBN-DLO 1997). A scientific article drew an even stronger conclusion: "the current practice of realizing ecological corridors will not solve the problem of fragmentation" (Reijnen and De Jong 1997). A report with the title Pulsing Veins, written by a national working group on ecological corridors, also indicated that many of the realized ecological corridors were too narrow to achieve connectivity (Beentjes and Koopman 2000).

An Alterra scientist confirmed these criticisms in an interview and added to this the important remark that at that time, such a message would not be welcomed by the ministry of LNV:

We said, this is not going to work [...], [the ecological corridors] were too long and narrow [...]. But that was not relevant at that time; there was no room to think about these things in the policy domain. They had just started [with the NEN] and then you should not start complaining (R1).

This was confirmed by a former LNV employee:

I said [...]: I know this map was not ideal. But if you had articulated these scientific criticisms at that moment, the entire NEN policy would be endangered. Biologists, 
all scientists, are very good at that. [They start] a scientific discussion about policy

which results in total confusion and no policy results (R4).

Clearly, articulating the criticisms regarding the lack of ecological efficacy of the ecological corridors would not be effective and it was better to wait for a political window of opportunity. Furthermore, it became clear that the ecological corridors planned by the regional governments would require a larger budget and a lot more hectares than anticipated:

There were too many and it would cost too much money (R4).

The financial arrangements of the ecological corridors were very attractive for the regional governments as it was very easy for them to have a certain area designated as an ecological corridor and to get financial support for it. The director general of LNV was very critical about some of the ecological corridors that were planned:

I found that there was some empty rhetoric behind the ecological corridors, dressed up bicycle paths I have called them, which were not evaluated in terms of ecological efficacy or whatsoever [...]. But at that point we could not get rid of them, even though financially they were a problem (R3).

A policy alternative was available. In line with its metaphorical title, the earlier cited report Pulsing Veins the report made a distinction between veins and arteries (Beentjes and Koopman 2000). The "veins," with which the ecological corridors were indicated, could only serve regional interests. What was needed to effectively combat the fragmentation of nature at a national scale was the development of "arteries": the robust corridors. Hence, the report not only provided scientific criticisms to the ecological corridors, but also a scientific argument for the introduction of a new policy alternative, the robust corridors. These corridors would be bigger and they would be effective in achieving connectivity on a national scale (Beentjes and Koopman 2000).

The next section will show that the combination of scientific arguments regarding the lack of ecological efficacy of the ecological corridors, political arguments regarding finances, together with the availability of a viable and scientifically founded policy alternative did, although not immediately, lead to policy change and the termination of the ecological corridors policy. However, the next section will also make clear that it proved difficult to end the implementation of the ecological corridors policy in practice.

\section{Attempts at termination}

This section will report on the termination of the ecological corridors policy and describe the three steps that were required to achieve the termination of this policy.

The first attempt: nature for people, people for nature

During the development of the new policy plan for nature in the late 1990s, the ecological criticisms to ecological corridors became increasingly widespread. The new policy plan, which was published in 2000 with the title Nature for People, People for Nature (LNV 2000), was a good opportunity to have those criticisms translated into policy. Some felt that this was necessary despite the fact that many people were enthusiastic about the original corridors. An employee of the ministry of LNV said: 
A lot of plans for the ecological corridors had already been made. There was resistance against change. It was really [...] slamming doors, angry people. [...] I did feel sorry for them, but at the same time, if you can scientifically show that [the corridors] are not working well, you have to be able to say it (R5).

Such a direct use of scientific knowledge in policy was quite remarkable and did not go unnoticed. The director general of LNV commented on it in a speech: "This process of [...] scientific development has been implemented in policy practice with world record speed" (Van der Zande 2004).

The Secretary of State of LNV, Faber, played an important role in actually committing herself to the alternative of the robust corridors. She wanted a new idea for her new nature policy document and she felt that she would be able to get financial backing for it. A LNV civil servant remembered:

At a certain point the new policy document had to be developed and there was the need to distinguish it from the former policy document. Well, a new Secretary of State, a new policy [...] Faber liked the idea of robust corridors and said: "it is an appealing concept, we can sell it and I can get money for it from Zalm [the minister of Financial Affairs]. [...] If I come with a fresh new policy with good arguments, I will get extra money. [...]". [...] And it worked (R5).

However, what was to become of the old ecological corridors? The Nature for People, People for Nature document contained a rather vague section on the ecological corridors. ${ }^{2}$ The section implied that the realization of the robust corridors would coincide with the realization of about half of the ecological corridors because they would spatially overlap. The realization of the remaining ecological corridors would not be funded by the central government. This meant that if the regional governments still wanted to realize them, they would need to fund themselves. This decision was not only informed by ecological arguments but also by financial arguments. A LNV civil servant explained:

Then it was decided, well there is not enough money, so how are we going to spend it. The national interest is in the robust corridors and the central government will not put effort in realizing the other ecological corridors. That is the responsibility of the regional governments (R6).

However, to the involved actors, the implications of this section were not al all clear. A LNV civil servant admitted that the policy document was not clear on this issue:

Well, the policy document contains some unclear sections,, about financing half and not the other half... a shady business (R7);

The implications of the policy document were also not clearly communicated. As a result, the policy document did not lead to any response from the regional governments. An employee of DLG (Dienst Landelijk Gebied, an agency of the ministry of LNV in charge of implementing the ecological corridors policy) remembered:

The communication on this issue was really bad and that was a big mistake. LNV should have communicated straightforwardly that they would no longer finance the ecological corridors (R8).

\footnotetext{
2 The actual text of the policy document is not repeated here because the policy jargon proved hard to translate and because translation would not do justice to its vagueness.
} 
A LNV civil servant added that the termination of the ecological corridors policy was not complete, because the underlying implementation mechanisms had not been ended:

I think that the regional governments have been formally informed, but the regional governments never realized that this implied that LNV would no longer finance the remaining ecological corridors. Furthermore, the financial regulations were not changed, which meant that DLG could not reject any financial requests for realizing the ecological corridors (R4).

In short, Nature for People, People for Nature contained a vague section in which the ecological corridors policy was formally terminated. However, the practical implications of this section were difficult to understand and they were communicated poorly to the regional governments. Even more so, the underlying financial and implementation arrangements were not terminated. It is therefore not surprising that this policy document did in fact not terminate the policy at all.

The second attempt: the agenda for a living countryside

Despite the official termination of the ecological corridors policy, in practice, the planning and realization of ecological corridors continued. The regional government assumed that those ecological corridors that would not spatially coincide with robust corridors would also be financed by LNV. The development of the Agenda for a Living Countryside -a policy document that aimed at enhancing economic, social, cultural, and ecological developments in the countryside- provided an opportunity to end these misunderstandings. A DLG employee that worked on this document remembered:

We were triggered by the problems that occurred because these ecological corridors refused to go away. [...] [The ecological corridors] were included [in the Agenda for a Living Countryside] as a terminated policy goal, also in the budget (R8).

In contrast to Nature for People, People for Nature, the text of this document was very clear: "Because of spatial overlap with the planned robust corridors, half of the ecological corridors will be realized. No budget has been reserved for the remaining ecological corridors (if desired, the regional governments can provide funding). Already existing (legally binding) commitments will be met. As of the publication of the Agenda for a Living Countryside, the central government will not make any new commitments for the realization of ecological corridors" (LNV 2004). This section did have an effect. A former employee of DLG, now working for LNV, describes his surprise when he read it:

Suddenly, it was announced that LNV had terminated the ecological corridors policy.

Well, that was a complete surprise. We [at DLG] did not see this coming (R9).

The Agenda for a Living Countryside was one step closer to the actual termination of the ecological corridors policy, but its clarity also triggered resistance. According to several interviewees, the regional governments were not happy:

[It] was a repetition of Nature for People, People for Nature, but then much stronger.

That was the moment that the regional governments started to complain (R8);

It was a difficult moment, because the regional governments argued; first there is the NEN, then we start working on it and now you change things again. They were really angry (R5); 
The regional governments said: 'hey, we have made legal and administrative commitments that we have to fulfill' (R10).

The resistance of the regional governments gave rise to a parliamentary debate about the ecological corridors. As the motion cited in the first section of this article showed, the Dutch parliament shared the concerns of the regional governments about the commitments that had already been made and urged Minister Veerman of LNV to make proper arrangements with the regional governments (Tweede Kamer 2005). It was clear that a final assessment would have to be made about which ecological corridors would be financed by the central government and which would not.

The final assessment

Minister Veerman realized that it was very important that the final assessment about the ecological corridors would be done properly in order to maintain good relations with both the parliament and the regional governments:

That was done to keep the parliament happy. They [parliament] had of course been influenced by the regional governments [...]. And Veerman wanted to keep good relations with them (R8);

The exercise to take a good look at which ecological corridors would be financed and which not, was initiated by Veerman to get parliament behind his robust corridors policy (R7).

This assessment was also seen as an opportunity to compensate for the mistakes made in the past. According to a LNV employee:

Well, the way it was done, in hindsight, you can criticize it. It was not done properly.

We just wanted to be done with [the ecological corridors]. That is why we started this exercise, to be able to finish it properly (R7).

The assessment process, which will be described below, makes clear that indeed the minister went to great lengths to satisfy the regional governments. The regional governments were allowed to participate in the assessment process and they managed to increase the amount of ecological corridors that would be financed by LNV by adding an ecological test.

The final assessment of the ecological corridors was carried out by a working group consisting of employees from LNV, the regional governments, and Alterra. The aim of this working group was to make an inventory of all planned ecological corridors and categorize them into five groups: (1) ecological corridors with legal commitments, (2) ecological corridors with important administrative commitments, (3) ecological corridors that were almost finished, (4) ecological corridors that contribute significantly to a robust corridor, and (5) ecological corridors with high ecological value. The first three groups were directly related to the issues that had come up in the parliamentary debate and were communicated to parliament in a letter (Veerman 2004). The fourth group was a direct result of the new robust corridors policy. The fifth group was new. According to a letter from the director of the nature department of LNV, it was added because the regional governments wanted it: "LNV has, partly because the regional governments insisted on it, decided to not only make a technical list but also assess the ecological efficacy of the ecological corridors" (Raaphorst 2005). 
In order to decide which ecological corridors would be put into group 5, all remaining ecological corridors that were not part of the first four groups were tested for ecological importance with the computer model Larch. ${ }^{3}$ The report called "financing ecological corridors" (LNV 2005) showed the results of the final assessment and the ecological test. Based on their relative contribution to the NEN, the ecological test ranked the ecological corridors into five categories. The working group decided that the first two categories "of essential interest" and "of considerable interest" would be financed by LNV. The remaining categories "of some interest," "of little interest," and "of no interest" would not be financed. Apart from these categories, some ecological corridors that constituted separate and autonomous ecosystems (mostly brook valleys) fell in a separate category. It was decided that these would be financed as well.

In a letter to parliament (Veerman 2005), the minister of LNV reported on the assessment process and on the outcomes of the assessment: "In the previous months, LNV together with the regional governments assessed how many hectares of ecological corridors have been planned and the extent to which legal and administrative commitments have been made. Also an assessment has been made about which ecological corridors contribute significantly to the realization of robust corridors and which ecological corridors have been completed for $75 \%$ or more. Those ecological corridors will be financed. Finally, an ecological assessment has made clear that some ecological corridors were of such ecological importance that I have decided to finance them" (Veerman 2005). The final outcome of the assessment was as follows: the regional governments had planned 19.816 ha of ecological corridors, of which 4.464 ha had already been realized; 6.039 of the remaining 15.352 ha would be financed and the remaining 9.313 ha would not be financed with funds from central government (Veerman 2005).

Several of the interviewees were quite pleased with the assessment process and its outcomes. According to a LNV civil servant:

"We have reached our goal in the sense that a large part [of the ecological corridors] is gone now, and that you don't have the problem of having to spend a lot of money on hectares that are just not effective" (R7).

An Alterra scientist comments on the transparency of the assessment process and the role of the computer model Larch:

In such moments, it is good to have something like Larch. It [the final assessment and the use of Larch] was very open and transparent. And because we had agreed beforehand on how we would deal with Larch, everybody accepted the outcomes of the assessment (R11).

Termination of ecological corridors policy had finally been achieved but not without effort and costs. It took two policy documents and a meticulous assessment process to terminate it. The final assessment made clear just how successful the concept of ecological corridors had been. In the end, over 900 ecological corridors were processed in the assessment (LNV 2005). It also made clear that the termination of ecological corridors policy would involve financial costs: policy termination could only be achieved after the minister had decided to finance a considerable part of the ecological corridors.

\footnotetext{
3 Landscape ecological Analysis and Rules for the Configuration of Habitat, a computer model that allows for the assessment of connectivity in landscapes.
} 


\section{Discussion}

One of the most surprising findings of the case study was the rapid implementation of ecological corridors policy. This policy was an instant success even though not all the requirements identified by the traditional literature on policy implementation were met. The policy was not clearly articulated in the Nature Policy Plan and intensive communication programs were apparently not required. The regional governments immediately started working with the ecological corridors without much active involvement from LNV. Until the final assessment, LNV was not even aware of the large amount of ecological corridors that had been realized and planned by the regional governments. The rapid implementation of the ecological corridors policy was based on two factors. First, as the interviewees recognized, the concept of ecological corridors was appealing. Second, the regional governments actively made use of the interpretive flexibility provided by the ecological corridors policy. The attractive financial arrangements and the lack of criteria about the efficacy of the ecological corridors allowed the regional governments to plan many more and a wider variety of them than LNV had anticipated. This shows that, in contrast to the traditional literature on policy implementation, sometimes policy implementation can be quite autonomous and effortless, depending on the possibilities of the implementing actors to reinterpret the policy according to the implementation context.

In contrast to what the termination literature suggests, arguments regarding economic efficiency and ecological efficacy were crucial in the termination of the ecological corridors policy. When scientists showed that the efficacy of the ecological corridors policy was limited and when it became clear that the ecological corridor policy would be very expensive, this knowledge lead to the decision to terminate the ecological corridors policy and replace it with the scientifically grounded robust corridors policy. Even though policy makers did worry about the costs of termination in the sense that they were aware that the regional governments would not be happy, efficacy and efficiency arguments apparently outweighed arguments related to political and emotional costs of termination.

This seems to be an exemplary case of instrumental knowledge utilization. Or is it? In line with insights from the field of Science and Technology Studies, such instrumental use of knowledge could only take place because it served political interests (Collingridge and Reeve 1986; Turnhout et al. 2008). The ecological corridors proved to be much too expensive and scientific arguments about the lack of ecological efficacy together with the availability of an ecologically effective policy alternative provided the necessary arguments to legitimate the termination of the ecological corridors policy. It proved much more difficult to achieve termination in practice and actually stop the implementation of the ecological corridors policy. In line with the traditional literature on implementation, poor communication and incomplete implementation of the decision to terminate this policy were the main reasons for this. Apparently, while the implementation of the ecological corridors policy did not depend on these factors, they were required for the implementation of the decision to terminate this policy.

Finally, the minister of LNV had to deal with the emotional, political, and financial costs of termination. The termination of the ecological corridors policy had damaged the relations with the regional governments and the minister understood that good relations with the regional governments were crucial for the success of the alternative robust corridors policy. In order to repair those relations, it was necessary to make appropriate arrangements and accept the unavoidable financial costs. A final assessment was made in which the regional governments were allowed to have a say. The outcome of the final 
assessment made clear that LNV would still have to finance about half of the hectares of the ecological corridors that were planned by the regional governments.

\section{Conclusion}

What is this case a case of? In relation to the theoretical discussion Sects. 2 and 5 of this article, it can be considered a case of policy implementation, policy termination, as well as policy succession. It can be seen as a case of policy implementation because it considers why the ecological corridors policy was implemented so rapidly and why it was so difficult to stop this implementation after this policy was formally abandoned and replaced with an alternative. It can be seen as a case of policy termination because it shows why the ecological corridors policy was terminated and describes the process that was required to achieve this termination in practice. Finally, it can be seen as a case of policy succession because it involved the replacement of the ecological corridors concept with the robust corridors concept while the overall policy goal to achieve connectivity in nature was not abandoned. Instead of making a choice, the point is that all three options are relevant for the analysis.

The focus on the termination aspect of the case study was inspired by the repeated claims in the literature about the lack of empirical and theoretical attention to the topic of termination. Related to this, this article argues that policy termination is not as rare as most of the literature on policy termination suggests. It can be considered as an inherent feature of policy change or succession in the sense that for a policy to be replaced by a new policy, the old policy and its implementation have to be terminated. However, this termination aspect was not treated in isolation. It was analyzed in context and this has resulted in an integrated account of the various aspects relevant for the analysis.

The analysis of the case study demonstrates the importance not only of analyzing policy processes in context, but also of loosening the boundaries between the stages in the policy cycle and the literatures related to these stages. This article has effectively integrated and applied insights from the literatures on policy implementation as well as policy termination. The analysis has shown that the factors identified in the literature that affect policy termination and implementation can be used to analyze and understand the case study. However, they cannot serve as universal theories with predictive power and the question which factors will enable or constrain policy termination and implementation can only be answered on a case by case basis.

Open Access This article is distributed under the terms of the Creative Commons Attribution Noncommercial License which permits any noncommercial use, distribution, and reproduction in any medium, provided the original author(s) and source are credited.

\section{Annex: list of interviews}

R1: Employee of Alterra: Interview early October, 2005, Wageningen, the Netherlands

R2: Employee of Alterra: Interview March 23, 2006, Wageningen, the Netherlands

R3: Employee of LNV: Interview January 25, 2006, The Hague, the Netherlands

R4: Employee of Alterra: Interview October 29, 2005, The Hague, the Netherlands

R5: Employee of LNV: Interview March 8, 2006, The Hague, the Netherlands

R6: Employee of LNV: Interview December 8, 2005, The Hague, the Netherlands

R7: Employee of LNV: Interview December 9, 2005, The Hague, the Netherlands 
R8: Employee of DLG: Interview February 3, 2006, The Hague, the Netherlands R9: Employee of LNV: Interview January 20, 2006, The Hague, the Netherlands R10: Employee of LNV, Interview March 8, 2006, the Hague, the Netherlands R11: Employee of the Dutch Environmental Assessment Agency: Interview October 29, 2005, Bilthoven, the Netherlands

\section{References}

Bardach, E. (1976). Policy termination as a political process. Policy Sciences, 7, 123-131. doi: 10.1007/BF00143910.

Beentjes, R. A., \& Koopman, J. C. M. (Eds.). (2000). Kloppende aders. Een impuls aan de realisatie van Ecologische Verbindingszones in Nederland. Ministerie van Landbouw, Natuurbeheer en Visserij, Den Haag.

Collingridge, D., \& Reeve, C. (1986). Science speaks to power, the role of experts in policy making. London: Frances Pinter Publishers.

Daniels, M. R. (1997). Symposium: Public policy and organization termination. International Journal of Public Administration, 20(12), 2043-2066. doi:10.1080/01900699708525286.

Daniels, M. R. (2001). Policy and organizational termination. International Journal of Public Administration, 24(3), 249-262. doi:10.1081/PAD-100000447.

Dekker, M., Turnhout, E., Bauwens, B. M. S. D. L., \& Mohren, G. M. J. (2007). Interpretation and implementation of ecosystem management in international and national forest policy. Forest Policy and Economics, 9, 546-557. doi:10.1016/j.forpol.2006.03.003.

De Leon, P. (2002). Commentary. Policy Studies Journal: The Journal of the Policy Studies Organization, 30(1), 47-50. doi:10.1111/j.1541-0072.2002.tb02127.x.

De Leon, P., \& Hernández-Quezada, J. M. (2001). The case of the national solidarity program in Mexico: A study in comparative policy termination. International Journal of Public Administration, 24(3), 289309. doi:10.1081/PAD-100000449.

Frantz, J. E. (1992). Reviving and revising a termination model. Policy Sciences, 25, 175-189. doi: 10.1007/BF00233747.

Frantz, J. E. (2002). Political resources for policy terminators. Policy Studies Journal: The Journal of the Policy Studies Organization, 30(1), 11-28. doi:10.1111/j.1541-0072.2002.tb02125.x.

Geva-May, I. (2001). When the motto is "till death do us part." The conceptualization and the craft of termination in the public policy cycle. International Journal of Public Administration, 24(3), 263-288. doi:10.1081/PAD-100000448.

Hanski, I., \& Gilpin, M. E. (Eds.). (1997). Metapopulation biology, ecology, genetics, and evolution. San Diego: Academic Press.

Hill, H. C. (2003). Understanding implementation: Street-level bureaucrats' resources for reform. Journal of Public Administration: Research and Theory, 13, 265-282. doi:10.1093/jopart/mug024.

Hogwood, B. W., \& Peters, B. G. (1982). The dynamics of policy change: Policy succession. Policy Sciences, 14, 225-245. doi:10.1007/BF00136398.

Lasswell, H. D. (1971). A pre-view of policy sciences. New York: Elsevier.

LNV. (1990). Natuurbeleidsplan, regeringsbeslissing. Ministerie van Landbouw, Natuurbeheer en Visserij. (Tweede Kamer, vergaderjaar 1989-1990, 21149, nrs. 2-3).

LNV. (2000). Natuur voor mensen, mensen voor natuur: Nota natuur, bos en landschap in de 21e eeuw. (Ministerie van Landbouw, Natuurbeheer, en Visserij).

LNV. (2004). Agenda voor een vitaal platteland, inspelen op veranderingen. (Ministerie van Landbouw, Natuurbeheer en Voedselkwaliteit).

LNV. (2005). Uitfinanciering ecologische verbindingszones. (Ministerie van Landbouw, Natuurbeheer en Voedselkwaliteit, Rapport Augustus 2005).

MacArthur, R. H., \& Wilson, E. O. (1967). The theory of island biogeography. Princeton: Princeton University Press.

Raaphorst, G. B. (2005). Technische lijst ecologische verbindingszones. (Brief van het ministerie van Landbouw, Natuurbeheer en Voedselkwaliteit aan de provincies, 11 februari 2005).

Reijnen, R., \& De Jong, M. (1997). Wordt de versnippering van de natuur voldoende teruggedrongen? Landinrichting, tijdschrift voor inrichting en beheer van het landelijk gebied, 37, 7 themanummer natuurverkenning ' $97,7-13$. 
RIVM, IKC-N, SC-DLO, IBN-DLO. (1997). Natuurverkenning 1997. (Rijksinstituut voor Volksgezondheid en Milieu, Informatie- en Kenniscentrum Natuurbeheer, Staring Centrum, Instituut voor Bos en Natuuronderzoek).

Sabatier, P. A., \& Mazmanian, D. A. (1981). The implementation of public policy: A framework of analysis. In D. A. Mazmanian \& P. A. Sabatier (Eds.), Effective policy implementation. Lexington, MA: Lexington Books.

Turnhout, E. (2003). Ecological indicators in Dutch nature conservation, science and policy intertwined in the classification and evaluation of nature. Amsterdam: Aksant/Het Spinhuis.

Turnhout, E., Hisschemöller, M., \& Eijsackers, H. (2007). Ecological Indicators: Between the two fires of science and policy. Ecological Indicators, 7, 215-228. doi:10.1016/j.ecolind.2005.12.003.

Turnhout, E., Hisschemöller, M., \& Eijsackers, H. (2008). Science in Wadden Sea policy: From accommodation to advocacy. Environmental Science and Policy, 11, 227-239. doi:10.1016/j.envsci.2007. 07.004.

Tweede Kamer. (2005). Gewijzigde motie van het lid Van Bochove c.s. ter vervanging van die gedrukt onder nr. 125. (Tweede Kamer der Staten-Generaal, Vergarderjaar 2004-2005, 29435 nr 142, 22 maart 2005).

Van der Zande, A. (2004). Tussen Onland en Verwonderland. (Zesde Victor Westhoff lezing, 1 April 2004).

Veerman, C. P. (2004). Afspraken evz's en robuuste verbindingen. (Brief van de minister van Landbouw, Natuurbeheer en Voedselkwaliteit aan de provincies, 17 Dec 2004, TRC 2004/8724).

Veerman, C. P. (2005). Uitfinanciering ecologische verbindingszones. (Brief van de minister van Landbouw, Natuurbeheer en Voedselkwaliteit aan de voorzitter van de Tweede Kamer der Staten-Generaal, 22 juni 2005, DN 2005/2080).

Visser, H. (2006). Ecologische verbindingszones, een reconstructie van het beleidsproces. (Master Thesis, Bos- en Natuurbeleid, Wageningen Universiteit).

Weiss, C. H. (1991). Policy research as advocacy, pro and con. Knowledge and Policy, The International Journal of Knowledge Transfer, 4(1\&2), 37-55.

Yanow, D. (1996). How does a policy mean? Interpreting policy and organizational actions. Washington, DC: Georgetown University Press. 